\title{
The Reform and Exploration of the Cultivation of Engineering Talents in Local Colleges and Universities
}

\author{
Yang Bo ${ }^{1, a}$ \\ ${ }^{1}$ Electronic Information Department, Foshan University, \\ Foshan, Guang Dong, China \\ a fsttww@sohu.com
}

\begin{abstract}
Education should be people-oriented, students' future survival and development is reflected in the fundamental quality of school education. All teaching requirements and teaching management should be as the ultimate goal, the education teaching to adapt to the needs of social development is the fundamental guarantee for the ultimate purpose of education teaching. This paper analyzes many factors that affect students' comprehensive ability on local university engineering education, and put forward some ideas and possible solutions from the educational philosophy, teaching reform, curriculum system, strengthening practice and improving the teachers' teaching ability.
\end{abstract}

Keywords: Education teaching, theory and practice, social development

\section{Introduction}

Foshan University is a comprehensive local undergraduate university, the students come almost $100 \%$ from the Pearl River Delta, the students' future survival and development are almost $100 \%$ in the Pearl River Delta.The guiding ideology of running school to adapt with it: " round development of innovative education, firmly establish the concept of quality education,to promote the local social progress, economic prosperity and development of science and education, to cultivate talents with innovative spirit and practical ability as the fundamental task of the school; Taking the undergraduate course teaching as the center, to seek

development, seek benefit with management, democracy

and pragmatic, reform and innovation, make the characteristic; Student has noble humanistic spirit, good scientific literacy and correct service consciousness for education the main line, to coordinate the healthy development of the discipline." School ideology is accurate, applied engineering personnel training should be geared to the needs of economic and social construction, production, management, service and so on, with high moral qualities, solid theoretical basis, wide knowledge,line of Ideological and moral quality is high, solid theoretical foundation, wide knowledge, strong ability of engineering practice, management and innovation capabilities for the senior engineering applied undergraduate talents. The rapid development of china's higher education in recent years, competition among colleges and universities is becoming increasingly fierce. The talent training mode should fully reflect its own characteristics of running a school. How to implement the teaching reform, increase student satisfaction to enhance the school's competitiveness, should be the school's competitiveness, should be discussed seriously study.

\section{Education should be geared to the needs of social development}

Foshan is the forefront of reform and opening up, the main industrial sectors are: home appliances, ceramics, plastics, textile and garment, electronics, industrial electronics, machinery, metal products, paper making, with a strong industrial base. The system mainly in the private economy, or state-owned economy supplementary. The main processing technology, high-tech products as a supplement. Products mainly for export, domestic sales as a supplement. The new enterprise system,employment mechanism alive. It has experienced the agricultural economy and industrial economy, began to enter the economy era of knowledge as based, the leading factor and determining power. It cannot do without innovation education, which directly promote the knowledge production, the growth of talent, and innovative talents in the knowledge economy to promote the knowledge for wealth, become a capital.The knowledge economy demands talents with innovative knowledge and the ability of the creative application of the knowledge. But the training process with a certain periodicity, so the development of education should have a certain forwardlooking,affected by the traditional planned economy thought, schools teach students still focusing on theoretical knowledge,but the theory of knowledge is not equal to the production technology, the production technology is not equal to the product, the enterprise operating.under the market economy need the talent for directly producing products. Under the past planned economy the talent comes into the state-owned enterprises, a year can not adapt for two years to adapt, two years can not adapt for three years to adapt, now the talents into the private sector under the market economy ,allowing the adaptation time is three months to half a year at most. School education, in particular, engineering education should work harder to adapt to social development requirements, to understand the 
demand and development trend of the society at present. Constantly looking for various industries existed employment opportunity, finding a job is not feel up to what work as what work, but the company think you can do what work and let you to serve as what work. At present, between school education, especially engineering education and social, there is quite a gap.

\section{The cultivation of students' comprehensive ability}

(1)To adapt to the social development, That is, pay attention to theory and practice to establish a new talent training mode theory and practice and establish a new talent training mode. To adapt to the social development, the establishment of a new talent training mode, fundamental purpose is to cultivate characteristic can meet a variety of talents of local needs, there is a space for one person in the fierce competition in the higher education stage. This requires for local professionals to tailor the required basic courses, professional basic courses, specialized courses, etc.,all the curriculum should serve as a starting point, focusing on training professionals, rather than generalist training. Using Using the training mode of both theoretical knowledge learning with practical ability training, training complex technical talent, the the maximum extent possible to meet social needs.

(2)To be adapted with the talent training plan and standardize the teaching management. The personnel training plan meeting the local social demand should have the following characteristics (1)Both course system and practice teaching system have paid attention, reflecting the principle of knowledge, ability, and quality coordinated development.. (2) Strengthen the professional courses, appropriate compression of public basic courses. (3) Set professional direction module courses for students on the basis of basic training to achieve professional goals to further broaden the students' professional face. (4)The extracurricular activities and social practice should be brought into the curriculum system, offers a broad category of elective courses, develops the student individuality, improve the comprehensive quality. (5) To set up new practical teaching system, highlighting the school characteristics. Further standardize the teaching management, developed with suitable teaching management, educational administration, materials management, practice teaching management etc..

(3) In order to improve the overall quality of students for the purpose of establishing a new performance appraisal system.The comprehensive quality level is the comprehensive reflection of ability structure efficiency, The school besides should implement comprehensive quality education, but also to establish the scientific and effective system of performance evaluation, the single mode is changed in school academic curriculum evaluation, the new evaluation system should not only reflect the student's records moral, intellectual, physical conditions, but should reflect the overall professional quality of students, if possible, should study the quantitative assessment, improve student awards regulations, and further promote the overall quality of education and improve overall quality of students, increase students' competitiveness, which is about to enter the community of students to help huge.

\section{Improve the comprehensive ability for the purpose of practice teaching}

The cultivation of practice teaching of the students' ability and comprehensive quality is particularly important, it should not belong to the theory teaching. In the personnel training plan should put practice teaching throughout the four years of the study, and set up system of practice teaching for a relatively independent of the theory and closely linked to the theoretical teaching. The experimental teaching, extracurricular activities and social practice bring in the curriculum system, in order to ensure the improvement of students' comprehensive practical ability.

(1)To expand the horizons, solid foundation, cultivate the students' learning interest and determine learning objectives. The students into the school are carried out a targeted professional knowledge education to enable students to fully understand the profession's past, present and future.. Organize the first and second grade students to visit and study, increased perceptions. Arrangements production labor for one week each semester, understand the productive situation on the professional, Improve students specializing in the production of their present skills. Through expert presentations and seminars, let the students have a better understanding of the professional production technology status and development trend. To guide students in a professional or a product as the object to write report, guide the students to the professional or a product for writing the investigation report object, get a comprehensive understanding of their own expertise, and improve the interest of learning.

(2)The reform of experimental teaching system, to improve the students' ability to solve practical problems For grade two or three students should strengthen the professional foundation and the professional reform the existing experimental teaching management system, establish experimental teaching quality assurance mechanisms professional teaching or professional responsibility of teachers, this is beneficial to both teaching and research work. Reforming the specialized verification experiments, the professional basic course, specialized course of theory teaching and experimental teaching are unified to complete the verification experiment in the theory teaching process. Set up an independent experimental courses,systematically study experimental methods, measurement theory, data analysis and data processing, master operations using of a variety of equipment, write rightly lab reports. Reform curriculum design, open comprehensive experiments, design experiments and system debugging experiment, improve students' ability to solve practical problems. 
(3)Carry out the education of product quality management system, let the students understand the whole process of production. For the fourth grade students should strengthen the production practice and the graduation design for two aspects, it should effort well the construction of production practice base. In 2009 arranged 10 students of grade 06 electronic to Shenzhen Tiandi Electronics Co., Ltd. for a period of 1 months of graduation practice, from the component screening, testing and debugging and the circuit manufacturing, to product testing out the factory, the students valet the actual production operation. Not only for the production of the entire process with a comprehensive insight and product quality management system, product quality assurance system have a basic understanding, Learn a lot of the knowledge of technical products that are not in school textbooks, for knowledge how to transform as the productive forces with experience, pull close the distance between the school and the community.

\section{Strengthen and improve the construction of teachers' team}

The quality of personnel training in Colleges and universities mainly depends on the quality of teachers in Colleges and universities, In high-speed development of higher education, the knowledge total inflation, interdisciplinary field constantly infiltration, many edge discipline continues to produce, and general use of information technology in higher education, for University teachers put forward higher requirements. While university teachers have a higher education, degree and professional knowledge, but a lack of systematic teaching theories of learning, since most engineering college teachers from school to school, lack of practical work experience, it is difficult to meet the requirements of entrepreneurship and innovation education. Although university teachers have a higher education, degree and professional knowledge, but a lack of systematic teaching theories learning, since most engineering college teachers from school to school, lack of practical work experience, it is difficult to meet the requirements of entrepreneurship and innovation education.

(1)Implement teacher qualification system. Raise the access threshold of university teachers, university teachers' education threshold raises to master graduate student, and gradually transition to the $\mathrm{PhD}$. On the professional orientation, professional ethics, education and teaching capacity requirements for fine instrument. To implement the system on First obtaining qualifications for teachers and then posting first qualified as a teacher and then for , change the existing change the existing first appointment after obtaining post qualification certificate for teachers of engineering colleges, for engineering college teacher should have related college teacher should have related working experience.

(2)Comprehensively enhance the comprehensive expertise of university teachers. The basic content of college teachers' professional qualities include knowledge, ability,professional cordiality, professional self in four parts. The knowledge part includes professional knowledge, general education and cultural knowledge and practical knowledge;The Ability part includes professional ability and the education teaching ability; The professional affection part including professional philosophy, professional aptitude, professional sentiment, etc; The professional self part include the content, the nature and the value by engaging in his own special occupation and understanding,

experience and monitoring.By engaging in his own special occupation behavior. Teaching is not only to impart knowledge, but also to create and extend knowledge, knowledge organized, make students more easy to accept, these require teachers to have certain scientific thinking ability. University teachers should not only have the ability to update knowledge, adjust the structure of knowledge, but also have the ability to study, master the rules of teaching and teaching method. University teachers should not only have the ability of teaching, but also have a certain scientific research ability, the combination of scientific research and classroom teaching is an effective way to improve the teaching quality of University teachers.

(3)Establish a variety of teacher development model. Focus on teachers' growth, and create an open, easy and harmonious teaching atmosphere is crucial to the promotion of teaching ability.To establish a suitable training system for individual development, pay attention to strengthening the pertinence, diversity, interaction and operation. The school held thought the lesson project seminar classes, teaching theory training classes, teaching skills training class, teaching skills e-learning classes network learning classes or send to Delivery to the teaching characteristics of college for training, visiting and other channels, to provide further opportunities for teachers, help teachers to improve teaching ability. According to the individual characteristics of teachers, scientifically designed their career, gradually improved teachers' cultural literacy in order to meet the continuous improvement of university teaching requirements.

\section{Conclusion}

To improve the ability of local university engineering talents to adapt to the society must be from the perspective of the education reform, from the social culture of social practice and so on many kinds of ways, it will go its own way, with the characteristics of local colleges and universities.According to the characteristics and development trend of intelligent measurement based on the analysis of intelligent automation testing course of conventional instruments and technology content, add artificial intelligent detection technology in the course of intelligent measuring contents in the teaching of the concept of BP artificial neural network for teaching practice of automatic detection and intelligent instrument. Into the experiment teaching in the classroom teaching content of the 
BP artificial neural network is used to design the piezoelectric vibration accelerometer zero output voltage compensation and nonlinear characteristics of the environment of multi parameter sensor intelligent detection system and discussed the conventional automatic control method and integration of artificial intelligence control method advantage. The students master the basic knowledge of BP artificial neural network and the basic methods by experiment. Through the teaching practice of the two students' knowledge teaching into artificial intelligence in intelligent detection technology and instrument course teaching and experiment teaching and good results have been achieved. In recent years, we do a lot of exploration in the teaching reform of intelligent measurement, made some achievements.

\section{References}

[1] Liú Yùtíng, "Discussion and Practice Research on the Training Mode of Innovative Talents in Some Colleges and Universities," China Education Innovation Herald , pp. 64-71, 2014.

[2] Ma Tingqi, Shi JiacUi, "University Talents Training Mode Reform and the Cultivation of Innovative Talents," Modern Educa-

tion Science, pp. 102-104, 2013.

[3] Wang Pingxiang, "Thoughts on Deepening training mode and innovation experimental zone construction," China University Teaching , pp. 72-76, 2014.

[4] Li Aimin, Yan chaode , Wu Liancheng, "Engineering Survey Practice Course Teaching Reform," Laboratory Research and Exploration , pp. 46-48, 2013.

[5] Xia Dongjun, Wang Shicheng, Tao Zeming, "Research on the Practice Teaching Reform of Surveying Course and Implementation," Laboratory Science, pp. 61-64, 2012.

[6] Li Denghua, "Teaching reform of Detection technology and instrument course for automation,"Computer Education, pp. 183-186,2010. 